\title{
The Correlation Between Anxiety and Coping Mechanisms in Patients with Renal Failure Undergoing Hemodialysis \\ ${ }^{1 s t}$ Adiratna Sekar Siwi Faculty of Health, Harapan Bangsa University adiratnasiwi@gmail.com

\author{
${ }^{2 n d}$ Azka Fathiyatir Rizqillah \\ Faculty of Health, Harapan \\ Bangsa University \\ fathiya.azka@gmail.com
}

\author{
${ }^{3 r d}$ Dwi Yulianti \\ Faculty of Health, Harapan \\ Bangsa University \\ yuliantidwi741@gmail.com
}

\begin{abstract}
Patients undergoing long-term hemodialysis will face various physical and psychosocial problems. Psychosocial problems include the inability to resume a normal lifestyle, self-reliance in life anxiety, depression, social isolation, loneliness, helplessness, and despair. Renal failure patients should be able to have self-durability during their illness. Patients with adaptive or maladaptive coping mechanisms show a change of physical, psychological, and social environments. A descriptive correlational design was used in the study. The sample size was $\mathbf{5 8}$ respondents. The sampling technique used was the total sampling technique. The research instrument was questionnaires, namely the Zung Self-Rating Anxiety Scale (ZSAS) and the Ways of Coping (WAYS). Data were analyzed using frequency distribution and the Chi-square Test. The results showed that most of the respondents were elderly at the age of 46-65 (37 respondents) $(63.8 \%)$, and males (32 respondents) $(55.2 \%)$, and undergoing hemodialysis for less than 6 months (38 respondents) $(65.5 \%)$. Most respondents experienced mild anxiety (51 respondents) $(87.9 \%)$. Most respondents had adaptive mechanisms (45 respondents) (77.6\%). There was no correlation between anxiety and coping mechanisms in patients with renal failure undergoing hemodialysis $(p$-value $=0172)$.
\end{abstract}

Keywords: coping mechanisms, anxiety, hemodialysis

\section{INTRODUCTION}

Chronic kidney disease or chronic renal failure is a progressive and irreversible disorder of renal function in which the ability of the kidneys fails to maintain metabolism, fluid balance, and electrolytes, and thus it can cause uremia [1]. Hemodialysis (HD) is a therapy of kidney function replacement that works to correct fluid, and electrolyte disturbance [2]. Hemodialysis for patients with chronic kidney disease can reduce the risk of damage to vital organs due to accumulation of toxic substances in the circulation, but this action does not cure or restore kidney function permanently [3].

Patients who undergo hemodialysis in the long term will face various problems, such as financial problems, difficulty in working, decreased sexual drive, depression, and fear of facing death, therefore their lifestyle must be changed since it can affect their enthusiasm for life [4]. Patients undergoing dialysis will experience a lack of control over their everyday life and social activities, loss of freedom, early retirement, disruption in family life, changes in self-image, and reduced self-esteem. This results in psychosocial problems, such as inability to continue his normal lifestyle, independence from living with anxiety, depression, social isolation, loneliness, helplessness, and despair.

Several factors that cause anxiety in renal failure patients who undergo hemodialysis are age, gender, knowledge level, personality type, environment, and situation. Some of the causes that often occur are seeing the tubes with the flow of blood, thinking about the costs incurred in hemodialysis, feeling afraid of being pierced by needles, and living with uncertain recovery [5].

Patients with renal failure who have good coping mechanisms will expect good health conditions and be able to adapt to changes both physically, psychologically, environmentally and socially. Besides, patients with renal failure who use maladaptive coping mechanisms are more likely to experience moderate and severe anxiety [4].

The purpose of the study was to find out the correlation between anxiety and coping 
mechanisms in patients with renal failure undergoing hemodialysis.

\section{METHODOLOGY}

A descriptive correlational research design was applied in the study. The population was 58 kidney failure patients in March 2019. The sample size was 58 respondents. The sampling technique used was total sampling. The study was conducted at Millitary Hospital of Wijayakusuma Purwokerto from May to June in 2019.

The instrument used in the study was questionnaires. The questionnaires employed were the Zung Self Rating Anxiety Scale (ZSAS) and Ways of Coping (WAYS). The ZSAS questionnaire is a questionnaire provided in English designed by William WK Zung. While the researchers used the questionnaires in Indonesian used as a measuring instrument of anxiety to test the validity that described the lowest score $(0,663)$ and the highest score $(0,918)$ [6]. The WAYS is a questionnaire from the Folkman in English then it was also translated into Indonesian and already examined its validity. The construct validity of questionnaires was tested using the Product Moment Correlation Coefficient. The results showed correlation coefficient r-count $(0,911)$ \& gt; r-table $(0,444)$, and it showed that the questionnaires were valid [7]. The researchers analyzed the data using univariate and bivariate analysis. The univariate analysis applied was frequency distribution, while the bivariate analysis used was the Chi-Square.

\section{FINDINGS AND DISCUSSION}

The study was conducted in June 2019. The number of respondents who met the inclusion criteria was 58 respondents. The results can be illustrated as follows:

1. Univariate Analysis

a. Characteristics of Respondents (Age, Gender and Length of HD Therapy)

Table 1 Frequency Distribution of Respondents (Age, Gender and Length of HD Therapy)

\begin{tabular}{lll}
\hline Characteristic & $\begin{array}{l}\text { Frequency } \\
(\mathbf{n})\end{array}$ & $\begin{array}{l}\text { Percentage } \\
(\%)\end{array}$ \\
\hline Aged & & \\
Teenagers (12-25 years old) & 1 & 1.7 \\
Adults (26-45 years old) & 20 & 34.5 \\
Elderly (46-65 years old) & 37 & 63.8 \\
\hline
\end{tabular}

\begin{tabular}{lcc}
\hline Gender & 32 & 55.2 \\
Male & 26 & 44.8 \\
Female & 38 & 65.5 \\
\hline Length of HD Therapy & 20 & 34.5 \\
Acute $(<6$ months $)$ & Chronic ( $\geq 6$ months) & Table 1 shows that most of the \\
\hline & respondents are elderly at the age of $46-65$ \\
(37 respondents) (63.8\%), males $(32$ \\
respondents) (55.2\%), and undergoing \\
hemodialysis for less than 6 months $(38$ \\
respondents) $(65.5 \%)$.
\end{tabular}

b. Respondents Anxiety Undergoing Hemodialysis

Table 2 Description of Respondents' Anxiety Undergoing Hemodialysis

\begin{tabular}{lll}
\hline Anxiety & $\begin{array}{l}\text { Frequency } \\
(\mathbf{n})\end{array}$ & Percentage (\%) \\
\hline Mild & 51 & 87.9 \\
Moderate & 7 & 12.1 \\
Severe & 0 & 0 \\
\hline Total & 58 & 100 \\
\hline
\end{tabular}

Based on table 2, it reveals that most respondents experience mild anxiety (51 respondents) (87.9\%).

c. Description of Coping Mechanisms of Respondents Undergoing Hemodialysis

Table 3 Description of Coping Mechanisms of Respondents Undergoing Hemodialysis

\begin{tabular}{lll}
\hline $\begin{array}{l}\text { Coping } \\
\text { Mechanisms }\end{array}$ & $\begin{array}{l}\text { Frequency } \\
(\mathbf{n})\end{array}$ & $\begin{array}{l}\text { Percentage } \\
(\%)\end{array}$ \\
\hline Adaptive & 45 & 77.6 \\
Maladaptive & 13 & 22.4 \\
\hline Total & 58 & 100 \\
\hline
\end{tabular}

Based on table 3, it shows that most respondents have adaptive mechanism (45 respondents) $(77.6 \%)$. 
(11.8\%). This showed that men have more risks of chronic renal failure than women because women have more estrogen hormones. The estrogen hormone serves to inhibit the formation of cytokines to inhibit osteoclasts and thus it is not excessively absorbed into the bones and thus calcium levels are balanced. Calcium has a protective effect in preventing the absorption of oxalate which can form kidney stones as one of the causes of chronic renal failure.

Based on the results of the study, the majority of respondents had undergone hemodialysis for less than 6 months (38 respondents) $(65.5 \%)$. The researchers assumed that many patients undergoing hemodialysis were still in the acute stage.

Based on table 4, it depicts that the majority of respondents with mild anxiety and an adaptive mechanism are 41 respondents $(70.7 \%)$. A small proportion of respondents with moderate anxiety and a maladaptive coping mechanism is 3 respondents $(5.2 \%)$. From the 2 variables above, there was no correlation between anxiety and coping mechanisms in patients with renal failure undergoing hemodialysis (p-value 0.167).

\section{Discussion}

1. Characteristics of Respondents (Age, Gender and Length of HD Therapy)

Based on the results of the study, the majority of respondents were elderly at the age of 46-65 (37 respondents) $(63.8 \%)$. The researchers assume that the elderly (45-65 years old) will experience a decrease in the function of one of the organs of the body that impact on health conditions. Furthermore, a progressive decrease in glomerular filtration rate might also be experienced by people over the age of 40 to 70 years approximately $50 \%$ of normal so that there is a decrease in the ability of the tubular reabsorption and urine concentration [1]. Decreased ability of the bladder to empty results in a risk of infection, obstruction, and decreased fluid intake, which are the risk factors for kidney damage.

Based on the findings, most of the respondents were males (32 respondents) (55.2\%). This result is following Tokala's study (2015) in which most respondents were males (30 respondents) (88.2\%) and only 4 females

\section{Description of Respondents' Anxiety Undergoing Hemodialysis}

Based on the results, of 58 respondents, it was found 51 respondents $(87.9 \%)$ experiencing mild anxiety. Based on the data from the ZSAS questionnaire, it can be stated that respondents experienced anxiety or discomfort because they had sleeping difficulty at night. From the results of the interviews, sleep disorders experienced by respondents was due to the long wait for the hemodialysis schedule and thus they felt tight or had decreased health. On the other hand, it revealed other symptoms showing that respondents rarely or never experienced fainting (which could be a complication of renal failure). Respondents realized that if they routinely underwent hemodialysis, complications were increasingly decreased and thus they could improve their health conditions.

This is in line with the other research in which all respondents experienced mild anxiety (183 respondents) (100\%) explaining that patients with chronic renal failure were accustomed to the hemodialysis so that they were fully aware of the hemodialysis procedure, thus controlling stressors could be handled [8]. Other researchers explore that patients with renal failure undergoing hemodialysis felt anxious at the first-time about needle pricks, the blood in the dialysis catheter, and the sounds of the alarm of the dialysis unit. Moreover, patients feel anxious how long they can live with the disease. 
A research in Japan showed that patients undergoing hemodialysis experienced mild anxiety $(65.9 \%)$, moderate anxiety $(12.8 \%)$, and severe anxiety (4.2\%). In Romania, it was found a high incidence of anxiety in Chronic Kidney Disease patients undergoing hemodialysis up to $69.3 \%$ and most of the patients experienced anxiety of $85.1 \%$. A research in India showed that patients undergoing hemodialysis therapy experienced anxiety (86.7\%). Patients undergoing hemodialysis more than 20 times often experienced anxiety due to vascular access problems and the effects of hemodialysis are muscle cramps, hypotension, headaches, nausea, vomiting, and chest pain [9].

Patients undergoing hemodialysis usually have a different response to the hemodialysis therapy, for example, the patient feel anxious about the situational crisis, a death threat, and the final result of the therapy [10].

\section{Description of Respondents' Coping Mechanisms Undergoing Hemodialysis}

Based on the results of the study, most of the respondents had an adaptive mechanism (45 respondents) (77.6\%). Based on the results of the questionnaire, respondents had confidence that the current hemodialysis therapy could help. However, few patients had a different schedule for hemodialysis therapy because respondents might change their schedules if their conditions had worsened. The patient's family did not often accompany the respondents during hemodialysis to ensure that the respondents had done the hemodialysis therapy well and to provide support.

Individual coping strategies are categorized into 4, namely family support, religious support, rejection and avoidance, and excitement. The main function of coping is to manage stressors. Besides, coping is control of problems that could reduce emotional responses to stressors, therefore it could be a healing or stress relief when individuals attempt to relieve stress and feel better [11].

Coping is referred to cognitive and behavioral responses to control stressors, both external and internal that can burden one's life [12]. Coping is a process used by someone to manage stress and handle stressful situations in life [12]. Research results showed that knowledge, awareness, family, religion, and duration of illness are important factors influencing self-care and self-management. Coping mechanisms are used by someone to deal with stressors including knowledge about his condition. It is stated that the more he knows about his conditions and treatments, the more he can handle the problem in which the resources within himself are in the form of individual beliefs, personality traits, and social support indicating that the more the social supports, the better the coping mechanisms [13].

The adaptive coping mechanisms of respondents were talking with others, finding more information about the problem, believing in miracles such as conducting worship and praying activities, doing physical exercises to reduce tension, making various activities to avoid stressful situations, and learning from past experiences. The most adaptive coping mechanism was praying or surrendering to God chosen by $82.05 \%$ of respondents [14].

\section{The Correlation Between Anxiety and Coping Mechanisms of Respondents Undergoing Hemodialysis}

Based on table 4, the majority of respondents with mild anxiety and an adaptive mechanism were 41 respondents $(70.7 \%)$. A small proportion of respondents with moderate anxiety and a maladaptive coping mechanism was 3 respondents $(5.2 \%)$. The results of the study revealed that there was no correlation between anxiety and coping mechanisms in patients with renal failure undergoing hemodialysis ( $p$-value 0.167 ).

The results of the study indicated the lower the anxiety level of a patient, the higher the patient's tendency to use adaptive coping mechanisms. Respondents with a low level of anxiety are likely to talk to the closest people and attempt to solve the problems effectively. Besides, the health workers often provide information related to the disease and give motivation to patients.

Chronic renal failure usually has no symptoms until it reaches an advanced stage. During the disease progression, patients experience several common symptoms such as lack of energy, difficulty concentrating, poor appetite, insomnia, muscle cramps, edema, dry 
skin, increased in urinary frequency, bruising, shortness of breath, and bone pain. Hemodialysis patients will have no humanenvironment interactions, which will cause stress. Hemodialysis therapy can prolong the life expectancy of patients with chronic renal failure and it affects physical, emotional, social and economic difficulties [15].

Problems that are often faced by hemodialysis patients are stress and even depression. Many research revealed that such actions can have an impact on changes in patients' lifestyle such as limited time and freedom, disruption in daily routine (family, marriage, and work), sleep disorders, boredom, fatigue, limited intake of fluids and food, and uncertainty about the future. Psychological stressors also include depression, helplessness, uncertainty in prognosis to patients with hemodialysis.

Other research confirms that hemodialysis patients use coping strategies to deal with the stress they encounter. Most of the patients used emotion-focused coping strategies, but they are more difficult to respond due to a lack of knowledge. The coping strategies used by renal failure patients depend on several factors including personal experience, social support systems, personal beliefs, available resources and genetic background [15].

The results of the study showed that patients undergoing hemodialysis have surrendered to God and seek social support as a coping strategy [16]. From other studies, it was indicated that hemodialysis patients do not know what to do unless they undergo hemodialysis routinely [17].

\section{CONCLUSIONS}

1. Most of respondents were elderly at the age of 46-65 (37 respondents) (63.8\%), and males (32 respondents) (55.2\%), and undergoing hemodialysis for less than 6 months (38 respondents) $(65.5 \%)$.

2. Most respondents experienced mild anxiety (51 respondents) (87.9\%).

3. Most respondents had adaptive mechanisms (45 respondents) (77.6\%).

4. There was no correlation between anxiety and coping mechanisms in patients with renal failure patients undergoing hemodialysis ( $p$ value 0.172 ).

\section{REFERENCES}

[1] Smeltzer dan Bare. 2013, buku ajar keperawatan medikal bedah Brunner dan Suddarth edisi 8. EGC. Jakarta

[2] Ignatavicius \& Workman. 2009. Medical NursingClients- Centered Collaborative Care. Elsevier

[3] Muttaqin, Arif dan Kumala Sari. 2014. Asuhan Keperawatan Gangguan Sistem Perkemihan. Salemba Medika. Jakarta

[4] Indanah, I., Sukarmin, S. and Rusnoto, R. 2018. Kualitas Hidup Pasien dengan Gagal Ginjal. Proceeding of The URECOL, pp.608-615. website : http://repository.urecol.org/index.php/proceeding/article/d ownload/242/238

[5] Alfiannur, F., Nauli, F. A., \& Dewi, A. P. 2015. Hubungan antara Kecerdasan Spiritual dengan Tingkat Kecemasan Pasien Gagal Ginjal Kronik yang Menjalani Hemodialisa. Jurnal Online Mahasiswa Program Studi Ilmu Keperawatan Universitas Riau.

[6] Latansia, Fikri.2016. Hubungan Tingkat Spiritualitas dengan Tingkat Kecemasan dan Mekanisme Koping Mahasiswa Tingkat Pertama FKIK UMY.

[7] Kamas, Annisa MW. 2017. Hubungan antara Kejadian Bullying dengan Mekanisme Koping pada Mahasiswa Penerima Program Bidikmisi Departemen Ilmu Keperawatan Fakultas Kedokteran Universitas Diponegoro. Skripsi : Ilmu Keperawatan Fakultas Kedokteran Universitas Diponegoro.

[8] Kamil, I., Agustina, R., \& Wahid, A. 2018. Gambaran Tingkat Kecemasan Pasien Gagal Ginjal Kronik Yang Menjalani Hemodialisis Di RSUD Ulin Banjarmasin. Dinamika Kesehatan Jurnal Kebidanan Dan Keperawatan, 9(2), 366-377

[9] Takaki J, Nishi T, Shimoyama H, Inada T, Matsuyama N, Kumano H, Kuboki T. 2003. Interactions Among a Stressor, Self-efficacy, Coping With Stress, Depression, and Anxiety in Maintenance Hemodialysis Patients. Medical Sciences-Psychiatry And Neurology. Volume: 29. Edisi: 3, 107-129.

[10] Doengoes, M. E., dkk. 2010. Rencana asuhan keperawatan. Jakarta: EGC.

[11] Silva, R.A.R.D.,Souza Neto, V.L.D., Oliveira, G.J.N.D., Silva, B.C.O.D., Rocha, C.C.T. and Holanda, J.R.R.. 2016. Coping strategies used by chronic renal failure patients on hemodialysis. Escola Anna Nery, 20(1): pp.147-154

[12] Yodchai, K., Dunning, T., Savage, S., \& Hutchinson, A. M. 2016. The role of religion and spirituality in coping with kidney disease and haemodialysis in Thailand. Scandinavian Journal of Caring Sciences, 31(2), 359367.doi:10.1111/scs. 12355

[13] Chatrung, C., Sorajjakool, S., \& Amnatsatsue, K. 2014. Wellness and Religious Coping Among Thai Individuals Living with Chronic Kidney Disease in Southern California. Journal of Religion and Health, 54(6), 2198-2211.doi:10.1007/s10943-014-9958-4

[14] Armiyati, Y. and Rahayu, D.A., 2014. Faktor yang berkorelasi terhadap mekanisme koping pasien ckd yang menjalani hemodialisis di rsud kota semarang (Correlating factors of coping mechanism on CKD patients undergoing Hemodialysis in RSUD Kota Semarang). In Prosiding 
study. BMC Nephrology 18:119.

[17] Issa, D. T. N. 2015. Stressors and Coping Strategies amongst Hemodialysis Patients in North of West Bank. Published Thesis Submitted for Partial Fulfillment of Master Degree in Community Mental Health Nursing at the Faculty of Graduate Studies at An-Najah National University, 